\title{
Differences in Fruit Size, Postharvest Pathology and Phytochemicals between Irvingia gabonensis and Irvingia wombolu
}

\author{
Ebimieowei Etebu ${ }^{1}$ \\ ${ }^{1}$ Department of Biological Sciences, Niger Delta University, Wilberforce Island, Bayelsa State, Nigeria \\ Correspondence: Ebimieowei Etebu, Department of Biological Sciences, Niger Delta University, Wilberforce \\ Island, Bayelsa State, Nigeria. E-mail: eetebu@yahoo.com
}

Received: August 21, 2012 Accepted: September 24, 2012 Online Published: October 10, 2012

doi:10.5539/sar.v2n1p52 URL: http://dx.doi.org/10.5539/ sar.v2n1p52

\begin{abstract}
Irvingia (bush mango) species are economically important trees, but studies aimed at their prospect for domestication did not take into account the potential differences between members of the Genus. Hence fruit size, postharvest pathology and phytochemicals of I. gabonensis and I. wombolu were studied. Results showed that whilst the mean weight, length, width and thickness of fruits of $I$. gabonensis were $125.08 \mathrm{~g}, 60.85 \mathrm{~mm}, 62.66 \mathrm{~mm}$ and $56.78 \mathrm{~mm}$, respectively, those obtained from $I$. wombolu were $86.08 \mathrm{~g}, 54.23 \mathrm{~mm}, 54.09 \mathrm{~mm}$ and $50.97 \mathrm{~mm}$, respectively. Difference in brownish-black rot fruit disease between the two Irvingia species was not significant $(P=0.05)$, but disease severity increased correspondingly with increase in storage days. Four genera of fungi (Aspergillus, Penicillium, Rhizopus and Mucor) were isolated from fruits of both Irvingia species, and I. wombolu was found to sustain a significantly lower fungal population $(7.76 \mathrm{E}+07 \mathrm{cfu})$ than I. gabonensis $(1.05 \mathrm{E}+08 \mathrm{cfu})$. High fungal population led to a correspondingly high severity of brownish-black rot disease. Fruits of both Irvingia species possessed all five phytochemicals (alkaloids, flavonoids, saponins, tannins and glucosides). However, whilst both species had the same amounts of flavonoids and glycosides, $I$. wombolu possessed relatively higher amounts of alkaloids, saponins and tannins than I. gabonensis. I. wombolu may be the preferred choice if domestication would be based on phytochemicals. In like manner, I. gabonensis may be the preferred choice for domestication if taste, weight and size of fruits were the parameters of interest.
\end{abstract}

Keywords: Irvingia fruits, postharvest pathology, Aspergillus, Rhizopus, Penicillium, Mucor, Brownish-black rot disease, phytochemicals

\section{Introduction}

Irvingia gabonensis and I. wombolu are important high-value indigenous multi-purpose tree species found in West and Central Africa (Harris, 1996; Lowe et al., 2000; Atangana et al., 2002). Prior to 1975, Irvingia gabonensis and Irvingia wombolu were clumped together as one species, Irvingia gabonensis, (Aubry-Lecomte ex O'Rorke). However, a distinction was made between the two forms of Irvingia gabonensis by Okafor (1975) who recognised I. gabonensis var. gabonensis as having a sweet edible pulp, and I. gabonensis var. excelsa, having a bitter inedible pulp. Following this distinction, Harris (1996) revised the taxonomy of the Irvingiaceae, splitting I. gabonensis (var excelsa), described by Okafor (1975) as the bitter variety, from I. gabonensis (var gabonensis), the sweet variety, to create Irvingia wombolu Vermoesen. The sweet variety is now simply named Irvingia gabonensis while the bitter one is Irvingia wombolu. I. gabonensis and I. wombolu look very similar, and indeed are often difficult to tell apart from herbarium specimens alone (Harris, 1996). However, there are characteristics that distinguish the two, most noticeably the edibility of the fruit mesocarp. Studies on Irvingia have often failed to identify which species is being analysed, therefore in some cases figures given for $I$. gabonensis are actually for I. gabonensis var. excelsa (I. wombolu ) (Atangana et al., 2001).

Irvingia gabonensis and I. wombolu are also called bush mango or African mango because the trees bear mango-like fruits (Matos et al., 2009). The fruits are broadly ellipsoid, green when unripe and yellow when ripe with a fleshy mesocarp. The onset of ripening predisposes the fruits to postharvest spoilage microorganisms such as Aspergillus and Botrytis species, whose actions on the fruit produce the brownish-black rot disease symptoms (Joseph \& Aworh, 1992; Etebu, 2012). Although the fresh fruits of Irvingia species have long been known to have a short shelf life after harvest (Joseph \& Aworh, 1992), a systematic assessment of postharvest spoilage of Irvingia fruits has been done only recently (Etebu, 2012), but this study did not take into account the potential 
differences between I. gabonensis and I. wombolu. Furthermore, whilst the presence of antioxidants and phytochemicals in Irvingia seeds with their corresponding nutritional, economic and health benefits have long been known (Agbor et al., 2005; Ndoye et al., 1997; Ngondi et al., 2005), the presence of phytochemicals in the fleshy mesocarp of the fruits has not been studied until very recently. Etebu (2012) while working with Irvingia fruits without separating I. gabonensis from I. wombolu showed that the amount of flavonoids in postharvest Irvingia fruits mesocarp decreased with the passage of days after harvest.

The domestication of indigenous fruit trees and their integration into diverse agroforests have been identified as important components of a strategy for the improvement of land use in Africa (Sanchez \& Leakey, 1997). In West Africa, Irvingia species top the list of non-timber forest products being clamored for domestication (Ndoye et al., 1997; Leakey et al., 2003), and are fastly becoming the trees of choice in agroforestry practices (Okafor, 1985, 1991; Okafor, et al., 1996; Leakey, 1999; Koyejo \& Omokhua, 2001). However, previous studies on fruit and seed characteristics (Anegbeh et al., 2003) which would stimulate domestication of the trees also did not take into account the potential differences between I. gabonensis and I. wombolu.

Hence in this research, the potential differences in postharvest fruit sizes, pathology and phytochemicals of two Irvingia species (I. gabonensis and I. wombolu) are evaluated. Findings from this work would avail us prerequisite information that would enable farmers and agro-allied practitioners to make informed decisions on the choice of Irvingia species to domesticate.

\section{Materials and Methods}

\subsection{Assessing Fruit Morphology of Irvingia Species}

Irvingia trees bearing sweet and bitter fruits were randomly identified and marked as I. gabonensis and I. wombolu respectively in natural forests situated in Ogbia $\left(4^{\circ} 47^{\prime} \mathrm{N} 6^{\circ} 20^{\prime} \mathrm{E}\right)$, Southern Ijaw $\left(4^{\circ} 42^{\prime} \mathrm{N} 5^{\circ} 58^{\prime} \mathrm{E}\right)$ and Yenagoa ( $\left.5^{\circ} 02^{\prime} \mathrm{N} 6^{\circ} 20^{\prime} \mathrm{E}\right)$ Local Government Areas (LGAs) of Bayelsa state, Nigeria. About 5-6 trees were marked for each of the two Irvingia species in every LGA. Forty fruits were thereafter harvested at random from all trees previously identified as I. gabonensis in each of the three LGAs during the rainy season in the month of July 2010 (each LGA representing a replicate). The procedure was also separately carried out with trees previously identified as I. wombolu in all three LGAs. Thereafter, the weight, length, width and thickness of the fruits were measured as described by Leakey et al. (2000). The mean score of forty fruits harvested from an LGA was recorded as data of a replicate. Hence fruit size data of each of the two Irvingia species was measured in three replicates (40 fruits per replicate).

\subsection{Assessing Postharvest Brownish-Black Rot Disease of Irvingia Fruits}

Irvingia trees bearing sweet and bitter fruits growing naturally in a forest situated in Amassoma, Southern Ijaw LGA $\left(4^{\circ} 42^{\prime} \mathrm{N} 5^{\circ} 58^{\prime} \mathrm{E}\right)$ of Bayelsa state, Nigeria, were identified and marked as I. gabonensis and I. wombolu respectively. Ninety fresh fruits were harvested from about 4-5 trees of I. gabonensis, divided into three replicates (30 fruits per replicate) and spread within three quadrats of about $1 \mathrm{~m} \times 1 \mathrm{~m}$ in an open field (temperature about $28^{\circ} \mathrm{C}$ ) for 16 days being the usual practice of locals who harvest the fruits. The three quadrants represented three replicates. On the $2^{\text {nd }}$ day of storage four fruits of $I$. gabonensis were randomly selected from all three replications (quadrants) and their postharvest spoilage status were individually assessed based on brownish-black rot disease symptom described by Etebu (2012), and the average disease score of 4 fruits was recorded as the score for each replicate. Assessment of postharvest spoilage status of the fruits was repeated on the 9th and 16th days of storage after harvest (DSAH) respectively. Severity of postharvest spoilage was determined visually by the proportion of fruit area affected by brownish-black rot disease and expressed in percentage as according to Etebu et al. (2003). The procedure was also separately done with fruits harvested from trees previously identified as $I$. wombolu. The percentage data of brownish-black rot disease of fruits from both tree species were separately arcsine transformed according to Gomez and Gomez (1984), and represented as transformed brownish-black rot disease (TBRD). The transformed brownish-black rot disease (TBRD) data was subjected to ANOVA using Generalized Linear Model of SPSS version 16.0 statistical software. Mean percentage data of brownish-black rot disease (TBRD) were further subjected to Tukey's mean separation test. Mean TBRD were thereafter de-transformed (weighted) and discussed hereunder.

\subsection{Determination of Postharvest Fungal Population and Assessment of Fungal Genera Associated with Postharvest Irvingia Fruits}

The postharvest Irvingia fruits assessed on days 2, 9 and 16 for brownish-black rot disease were further processed to determine the fungal population and predominant fungal genera associated with Irvingia species' fruits exposed in the field at ambient temperature. All fruits selected for assessment of postharvest disease on 
these days were separately surface disinfected in $0.7 \%$ Sodium hypochlorite solution as according to Etebu et al. (2003) and rinsed in plenty of sterile distilled water. $200 \mathrm{~g}$ of the fruits' mesocarp was thereafter sliced out and blended with a household blender for 30secs under aseptic conditions. The resultant slurry was made up to $200 \mathrm{mls}$ with sterile distilled water, serially diluted and plated onto Petri dishes containing Potato dextrose agar (Oxoid Ltd, Hampshire, UK) previously prepared according to manufacturer's prescription, and integrated with $50 \mu \mathrm{g} \mathrm{ml}^{-1}$ each of streptomycin and tetracycline according to Etebu et al. (2003). The plates were thereafter incubated at ambient room temperature for 3 days. At the end of 3 days colony forming units were counted and the fungal population was expressed as colony forming units per gram of Irvingia fruit. Colonies were thereafter repeatedly subcultured after every three days onto newly prepared agar plates until pure cultures were obtained. Fungal colonies were thereafter transferred onto Sabouraud dextrose agar (Oxoid Ltd, Hampshire, UK) and incubated in a sporulating chamber under black light for 3 days (adapted from Etebu et al., 2005), and identified based on macroscopic and microscopic examination according to Alexopoulos (1962) and Barnett and Hunter (1972).

\subsection{Screening of Phytochemicals in Postharvest Irvingia Gabonensis Fruit}

Two days after the experiment aimed at assessing postharvest brownish-black rot disease of Irvingia fruits was set up, just when the fruits began to ripe, mesocarp of the same fruits assessed for postharvest brownish-black rot disease were sliced and pounded together in a mortar to form a composite sample (Fruits of the two Irvingia species were treated separately). The resultant paste was mixed with equal amount of water (weight/volume) to form Irvingia fruit waste extract, and screened to determine the presence of various phytochemicals (Alkaloids, flavonoids, saponins, tannins and glucosides) according to Harborne (1973), Sofowora (1993) and Trease and Evans (1989).

Test for alkaloids: $5 \mathrm{ml}$ of $2 \%$ hydrochloric acid was added to $2 \mathrm{ml}$ of extract in a test tube and boiled in a water bath for 5 mins. The mixture was left to cool and was thereafter filtered. To $2 \mathrm{ml}$ of filtrate was added $1 \mathrm{ml}$ of Mayer's reagent. The formation of a creamy white precipitate indicated the presence of alkaloids.

Test for flavonoids: $8 \mathrm{ml}$ of ethyl acetate was added to $2 \mathrm{ml}$ of extract in a test tube and brought to boiling for 1 $\mathrm{min}$ in a water bath. It was thereafter left to cool and filtered. $4 \mathrm{ml}$ of the resultant filtrate was then mixed with 1 $\mathrm{ml}$ of $1 \%$ Aluminium chloride solution. The formation of a yellow upper layer which persists in the presence of 1 $\mathrm{ml}$ dilute ammonia solution indicates the presence of flavonoids. The relative intensity of the yellow colour was noted with respect to Irvingia species.

Test for saponins: $5 \mathrm{ml}$ of distilled water was added to $1 \mathrm{ml}$ of Irvingia fruit waste extracts and boiled in a water bath for $5 \mathrm{mins}$. The mixture was then filtered while hot. To $1 \mathrm{ml}$ of filtrate 2 drops of olive oil was added in a test tube. The tube was thereafter corked and shaken vigorously for about 60 secs. The formation of a stable frost indicated the presence of saponins. The relative increase in frost was noted and discussed in relation to the Irvingia species under study.

Test for tannins: $2 \mathrm{ml}$ of Irvingia fruit extract was added to $10 \mathrm{ml}$ of distilled water in a test tube and boiled in a water bath for 5 mins. The resultant mixture was filtered while hot and allowed to cool. To $1 \mathrm{ml}$ of filtrate was added $1 \mathrm{ml}$ of ferric chloride. A bluish-black or brownish-green precipitate indicated the presence of tannins. A relative increase in the amount of precipitate indicated a corresponding higher amount of tannins present.

Test for glucosides: $10 \mathrm{ml}$ of distilled water was added to $2 \mathrm{ml}$ of Irvingia fruit extract in a test tube, boiled for 5 mins in a water bath and filtered on cooling. $5 \mathrm{ml}$ of the filtrate was thereafter separately added to $1 \mathrm{ml}$ each of Fehling solutions A and B respectively. The resultant mixture was then returned to the water bath and boiled for 2 mins. The formation of a brick red precipitate indicated the presence of glucosides. The relative increase in precipitate was treated as a correspondingly higher amount of glucosides present

\section{Results}

The fruits of both I. gabonensis and I. wombolu were observed to be delineated with respect to size, fungal population during spoilage, and inherent phytochemicals. The morphology of fruits of the two species of Irvingia (I. gabonensis and I. wombolu) were ellipsoidal (Figure 1) but were significantly $(P \leq 0.05)$ different with respect to weight, length, width and thickness (Table 1). The mean weight, length, width and thickness of fruits of I. gabonensis were $125.08 \mathrm{~g}, 60.85 \mathrm{~mm}, 62.66 \mathrm{~mm}$ and $56.78 \mathrm{~mm}$, respectively, whilst those obtained from $I$. wombolu trees were $86.08 \mathrm{~g}, 54.23 \mathrm{~mm}, 54.09$ and $50.97 \mathrm{~mm}$, respectively. Similarly, the fruits of I. gabonensis were observed to sustain a significantly higher fungal population during decay in comparison to $I$. wombolu. Whilst overall weighted mean fungal population isolated from one gram of I. gabonensis fruit was $1.05 \mathrm{E}+08$, only 7.76E +07 was isolated from I. wombolu after 16 days of storage under the same conditions. Difference in 
severity of brownish-black rot disease however, was not significant $(P=0.05)$ between the two Irvingia species (Table 1). A linear regression graph further showed that the severity of brownish-black rot disease was positively related to the number of fungi associated with fruits of both plant species $\left(\mathrm{r}^{2}=97.02 \%\right.$ for $I$. gabonensis and $\mathrm{r}^{2}=$ 98.53\% for I. wombolu) (Figure 2).

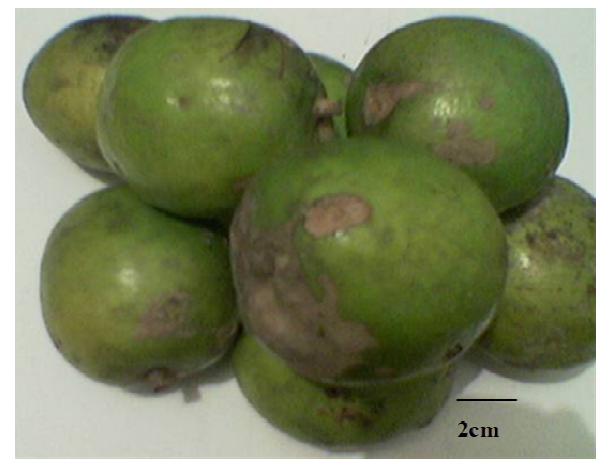

Unripe Irvingia gabonensis fruits

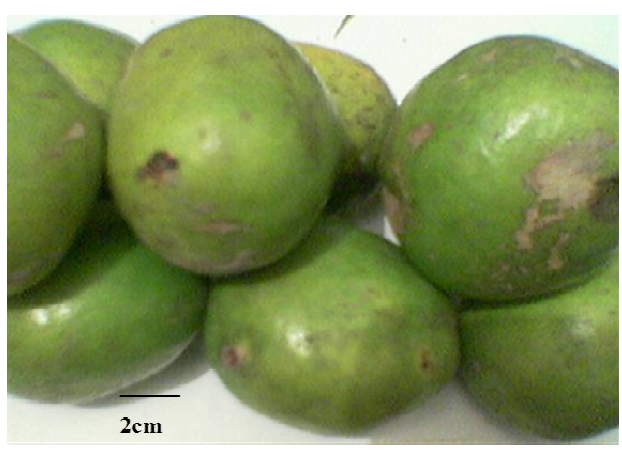

Unripe Irvingia wombolu fruits

Figure 1. Unripe Irvingia fruits on the day of harvest
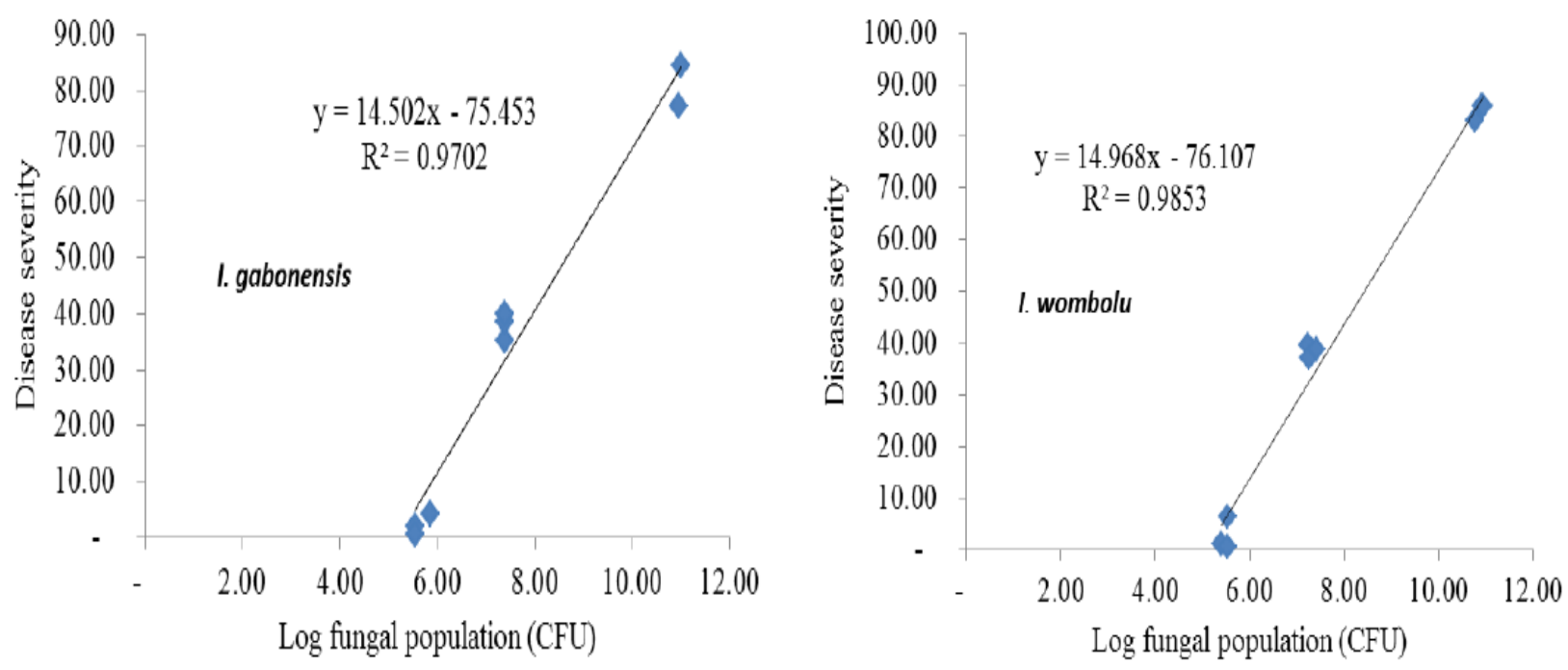

Figure 2. Relationship between fungal population and brownish-black rot disease of Irvingia fruits during spoilage

Table 1. Postharvest fruit size, fungal population and postharvest disease of Irvingia fruits

\begin{tabular}{ccccccccc}
\hline \multirow{2}{*}{ Species } & \multicolumn{3}{c}{ Fruit morphology (Mean scores) } & \multicolumn{2}{c}{$\begin{array}{c}\text { Mean Fungal } \\
\text { population/g Irvingia }\end{array}$} & \multicolumn{2}{c}{$\begin{array}{c}\text { Mean } \\
\text { Brownish-black rot } \\
\text { disease }\end{array}$} \\
\cline { 2 - 9 } & $\begin{array}{c}\text { Weight } \\
(\mathrm{g})\end{array}$ & $\begin{array}{c}\text { Length } \\
(\mathrm{mm})\end{array}$ & $\begin{array}{c}\text { Width } \\
(\mathrm{mm})\end{array}$ & $\begin{array}{c}\text { Thickness } \\
(\mathrm{mm})\end{array}$ & $\begin{array}{c}\text { Log } \\
\text { Pop. }\end{array}$ & Wted Pop & TBRD & WBRD \\
\hline I. gabonensis & $125.08^{\mathrm{b}}$ & $60.85^{\mathrm{b}}$ & $62.66^{\mathrm{b}}$ & $56.78^{\mathrm{b}}$ & $8.02^{\mathrm{b}}$ & $1.05 \mathrm{E}+08$ & $40.32^{\text {ns }}$ & 41.87 \\
I. wombolu & $86.08^{\mathrm{a}}$ & $54.23^{\mathrm{a}}$ & $54.09^{\mathrm{a}}$ & $50.97^{\mathrm{a}}$ & $7.89^{\mathrm{a}}$ & $7.76 \mathrm{E}+07$ & $42.01^{\mathrm{ns}}$ & 44.79 \\
Mean & 105.58 & 57.542 & 58.37 & 53.87 & 7.96 & $9.12 \mathrm{E}+07$ & 41.165 & 43.33 \\
\hline
\end{tabular}

Wted Log Pop = Weighted (detransformed) log fungal population; TBRD =Arcsine-Transformed brownish-black rot disease; WBRD = Weighted (detransformed) brownish-black rot disease. 
Apart from Irvingia species variety, fungal population associated with fruits undergoing decay was also dependent on days of storage after harvest (DSAH) (Table 2). The fungal population increased correspondingly as the number of days of storage after harvest increased. Overall mean Log population of fungi associated with $1 \mathrm{~g}$ of Irvingia fruits after 2, 9 and 16 days of postharvest storage were 5.57, 7.34 and 10.95, respectively (Table 2). Similarly, the progression and severity of brownish-black rot disease of postharvest Irvingia fruits were influenced by the days of storage after harvest (DSAH). Disease severity of both species of Irvingia progressively increased as the fruits aged through senescence after harvest (Table 2). Mean arcsine transformed severity of brownish-black rot disease of the fruits after 2, 9 and 16 days of storage were 2.42, 38.13 and 82.95, respectively (Table 2).

Table 2. Progression of brownish-black rot disease and population of fungi associated with Irvingia fruits during postharvest storage

\begin{tabular}{lll}
\hline Irvingia species/DSAH & $\begin{array}{l}\text { Mean Log fungal } \\
\text { population } \pm \text { S.E. }\end{array}$ & $\begin{array}{l}\text { Mean } \\
\text { TBRD } \pm \text { S.E. }\end{array}$ \\
\hline DSAH $=2$ & & \\
I. gabonensis & $5.64 \pm 0.10$ & $2.18 \pm 1.06$ \\
I. wombolu & $5.49 \pm 0.05$ & $2.65 \pm 1.87$ \\
DSAH $=9$ & & \\
I. gabonensis & $7.38 \pm 0.00$ & $37.84 \pm 1.43$ \\
I. wombolu & $7.30 \pm 0.05$ & $38.43 \pm 0.67$ \\
DSAH $=16$ & & \\
I. gabonensis & $11.02 \pm 0.05$ & $80.94 \pm 2.09$ \\
I. wombolu & $10.88 \pm 0.05$ & $84.96 \pm 0.99$ \\
\hline
\end{tabular}

$\mathrm{DSAH}=$ Days of storage after harvest; TBRD=Brownish-black rot disease (Arcsine transformed); S.E. $=$ Standard error.

Table 3. Relative occurrence of fungal species associated with different species Irvingia fruits during spoilage

\begin{tabular}{lcccc}
\hline \multirow{2}{*}{ Irvingia species/DSAH } & \multicolumn{4}{c}{ Frequency (\%) occurrence of fungal species } \\
& Aspergillus sp & Penicillium sp & Rhizopus sp & Mucor sp \\
\hline$\underline{\mathrm{DSAH}=2}$ & 25.00 & 12.50 & 25.00 & 37.50 \\
I. gabonensis & 28.57 & - & 28.57 & 42.86 \\
I. wombolu & & & & \\
$\underline{\mathrm{DSAH}=9}$ & 30.77 & 23.08 & 23.08 & 23.08 \\
I. gabonensis & 7.14 & 14.29 & 57.14 & 21.43 \\
I. wombolu & & & & \\
DSAH =16 & - & - & 25.00 & 75.00 \\
I. gabonensis & - & - & 25.00 & 75.00 \\
I. wombolu & 15.25 & 8.31 & 30.63 & 45.81 \\
Overall mean & & & & \\
\hline
\end{tabular}

DSAH=Days of storage after harvest.

Four genera, Aspergillus spp., Penicillium spp., Rhizopus spp. and Mucor spp. were isolated from postharvest Irvingia fruits. Overall mean frequency of occurrence of these genera of fungi after 16 days of storage were $15.25 \%, 8.31 \%, 30.63 \%$ and $45.81 \%$ respectively (Table 3 ). Whilst all four genera were isolated from $I$. gabonensis fruits on the $2^{\text {nd }}$ day of harvest, only three genera Aspergillus spp., Rhizopus spp. and Mucor spp. were isolated from I. wombolu fruits on the same day after harvest (Table 3). Rhizopus and Mucor species were 
predominant on the fruits on the $2^{\text {nd }}$ and $16^{\text {th }}$ day of storage after harvest irrespective of the Irvingia species variety. Whilst Rhizopus sp. (57.14\%) was the predominant fungal species isolated from $I$. wombolu fruits on the $9^{\text {th }}$ day in storage, Aspergillus spp $(30.77 \%)$ was the predominant in I. gabonensis fruits under the same conditions of storage.

Table 4. Relative amount of phytochemicals inherent in two species of Irvingia

\begin{tabular}{llllll}
\hline & \multicolumn{5}{c}{ Phytochemicals } \\
\cline { 2 - 6 } Irvingia species & Alkaloids & Flavonoids & Saponins & Tannins & Glycosides \\
\hline I. gabonensis & + & ++ & + & + & + \\
I. wombolu & ++ & ++ & +++ & ++ & + \\
\hline
\end{tabular}

+ : Low intensity of precipitate/colour indicating presence of phytochemical.

++: Moderate intensity of precipitate/colour indicating presence of phytochemical.

+++: High intensity to of precipitate/colour indicating presence of phytochemical.

Five groups of phytochemicals (alkaloids, flavonoids, saponins, tannins and glucosides) investigated in this work were detected in the mesocarp of postharvest Irvingia fruits. Postharvest fruits of both I. gabonensis and I. wombolu were observed to possess all the five phytochemicals (Table 4). Although postharvest fruits of both Irvingia species contained all the phytochemicals studied in this work, the relative amount of each phytochemicals varied between them. Whilst both species had about the same amount of flavonoids and glycosides, I. wombolu possessed relatively higher amount of alkaloids, saponins and tannins when compared to I. gabonensis (Table 4).

\section{Discussion}

Results from this work showed that postharvest fruits of Irvingia gabonensis and I. wombolu were different in many ways. The fruits of $I$. gabonensis were heavier, longer, wider and thicker than those of $I$. wombolu. Whilst the fruits of I. gabonensis weighed $125.08 \mathrm{~g}$ those of $I$. wombolu weighed $86.08 \mathrm{~g}$. Previous studies undertaken by Atangana et al. (2001) that did not differentiate between the two species showed that the mean weight of Irvingia fruits from two different villages were $99 \mathrm{~g}$ and $107 \mathrm{~g}$ respectively. The mean weight of all fruits obtained in this present work was $105.58 \mathrm{~g}$, and this would be comparable to the results of Atangana et al. (2001) if $I$. gabonensis and I. wombolu were not treated separately. Similarly, another related work that also did not differentiate between the two species of Irvingia showed that the mean weight of Irvingia fruits from Ngomedzap village in Cameroun was $103.8 \mathrm{~g}$ (Leakey et al., 2000). Even though differences in Irvingia fruit weight have been reported amongst fruits obtained from different locations (Atangana et al., 2001; Leakey et al., 2000) they did not differ as a function of the different land uses (homegardens, cocoa farms, crop fields or fallows) (Atangana et al., 2001).

Whilst the average weight of Irvingia fruits (ie across both species under investigation) was comparable to earlier reports, the relationship between fruit length and width in literature has been inconsistent. Results in this work showed that fruits of Irvingia gabonensis were generally wider $(62.66 \mathrm{~mm})$ than they were long $(60.85 \mathrm{~mm})$ (Table 1). On the other hand, the length $(54.23 \mathrm{~mm})$ and width $(54.09 \mathrm{~mm})$ of fruits of $I$. wombolu were about the same but Atangana et al. (2001) showed that Irvingia fruits were consistently greater in length than in width. Inconsistent with the findings of Atangana et al. (2001), an earlier report by Leakey and associates (2000) had shown that significant differences exist between trees with respect to fruit length and width. According to them, fruits of some Irvingia trees were longer than they were wide whilst some others had fruits that were greater in width than in length. Conflicting measurements of length and width of Irvingia fruits could have arisen from the fact that different workers may have measured the fruits, especially the width from different positions/orientations. The length, width and thickness described by Leakey et al. (2000) was adopted in this work, and that probably explains why both results were comparable but seemed to vary from those of Atangana et al. (2001). As earlier on noted, previous works on fruit measurements did not differentiate between $I$. gabonensis and $I$. wombolu, hence results obtained and reported by previous workers may not be sufficient for agriculturist and agro-allied practitioners to make an informed choice on which to domesticate. Results from this work clearly showed that I. gabonensis (the sweet variety) has bigger fruits when compared to I. wombolu (the bitter variety). 
In addition to morphology an attempt was made to delineate the fruits of I. gabonensis and I. wombolu with respect to their postharvest disease status and associated fungal composition and population. Results showed that postharvest Irvingia fruits were prone to spoilage irrespective of the species involved. Whilst brownish-black rot disease severity was not significantly $(P=0.05)$ different among fruits from the two plant species (Table 1$)$ the percentage decay increased with increase in postharvest days (Table 2). The fruits ripened as early as 2-3 days of storage after harvest, but with insignificant levels of symptoms of disease. Earlier works had shown that brownish-black rot disease symptom appeared on the fruits only after they had ripened, and progressed thereafter (Joseph \& Aworh, 1991, 1992; Etebu, 2012). Fruits are generally protected by differentiated integumentary structures which serve as barriers to microbial invasion. However, fruit physiology changes as fruits age during development, especially when ripening occurs and renders the fruit susceptible to microbial attack (Prusky \& Keen, 1993).

Four genera of fungi (Aspergillus, Penicillium, Rhizopus and Mucor) were isolated from postharvest fruits of the two species of Irvingia studied in this work. Previous results of fungal genera isolated from decaying Irvingia fruits have been inconsistent. Whilst Joseph and Aworh $(1991,1992)$ reported isolating Aspergillus sp., Botrytis sp. and Penicillium sp, a more recent work by Etebu (2012) showed that Mucor sp. was also isolated alongside Aspergillus sp., Botrytis sp. and Penicillium sp. Aspergillus and Botrytis species have been reported as being responsible for the brownish-black rot disease symptom of Irvingia fruits (Joseph \& Aworh, 1992).

Contrary to an earlier work which showed that Mucor sp. was associated only with completely decayed Irvingia fruits (Etebu, 2012), Mucor sp. was observed to be associated with mesocarp of postharvest fruits of the two Irvingia species as early as two days after harvest. Whilst Rhizopus and Mucor species were observed in this work as the most predominant genera of fungi associated with postharvest Irvingia fruits (Table 3), Botrytis and Mucor species were the predominant spoilage fungi on all varieties of strawberry with Rhizopus species being less important (Dennis \& Davis, 1977). More interestingly, the relative importance of spoilage fungi on a given fruit has been shown to change depending on variety of fruit involved, site and season of storage (Dennis \& Davis, 1977; Dennis et al., 1979). This probably explains the slight difference in the postharvest fungal quality of Irvingia fruits observed in this work from previous earlier works.

Species of fungal genera isolated from postharvest Irvingia fruits in this work have been associated with various plant and secondary food rot. Although they are usually not primary plant pathogens, they are often encountered as storage fungi on plant products (Kozakiewicz, 1989; Beresford et al., 2006; Perrone et al., 2007; Ilondu, 2011; Kobina \& Ebenezer, 2012). The fruits of I. gabonensis were observed to sustain a significantly higher number of fungi during decay in comparison to I. wombolu (Table 1).

Studies on fungi associated with postharvest Irvingia fruits have been essentially qualitative without any regard to population (Joseph \& Aworh 1991, 1992; Etebu, 2012). The significant $(P \leq 0.05)$ difference between $I$. gabonensis and $I$. wombolu with respect to fungal population may be attributed to differences inherent in them. Additionally, whilst postharvest fruits of both species possess similar combination of phytochemicals their relative amounts varied between them. Both species had about the same amount of flavonoids and glycosides, but $I$. wombolu possessed relatively higher amount of alkaloids, saponins and tannins when compared to $I$. gabonensis (Table 4).

Alkaloids are the most prominent phytochemicals occurring in plants, and play very crucial roles in defending the plant against herbivore, fungi, bacteria, viruses, and even other competing plants (Ashihara et al., 2008; Wink, 1988). Similarly, experiments have shown that saponins also protect the plant wherein it occurs against microorganisms (Mert-Türk, 2006). Tannins are astringent bitter plant polyphenols that binds to and precipitate proteins; they complex with leaf proteins, and exoenzymes from soil microorganisms, and in so doing, adversely affect nitrogen availability (Kraus et al., 2004; Nierop et al., 2006). The relatively higher amount of these phytochemicals in I. wombolu might be the cause of the lower fungal population compared to I. gabonensis. The most noticeable characteristic that distinguished the two species of Irvingia studied in this work was the edibility of the fruit mesocarp. Both tannins and alkaloids found in this work to be in relatively high amounts in the fruits of $I$. wombolu could be responsible for their bitter taste.

Both Irvingia species were observed to possess about the same amount of flavonoids (Table 4). Flavonoids occur in most plants, and they are the pharmacologically active constituents in many herbal plant medicines (Parsaeimehr et al., 2011). Flavonoids have been shown to protect the gastrointestinal (GI) tract, having antispasmodic, antidiarrhoeal, antibacterial, antisecretory and antiulcer properties, as well as strong antioxidant capacities (Di Carlo et al., 1993; La Casa et al., 2000; Sunairi et al., 1994; Isomoto et al., 2005; Rice-Evans et al., 1997). This present work has shown that the two Irvingia species investigated in this work could not be 
delineated by the amount of flavonoids they possess. So the choice to domesticate any of them would not be based on flavonoids. However, if one's interests of phytochemicals are alkaloids, saponins or tannins, I. wombolu would be the preferred choice for domestication. In like manner, I. gabonensis would be the preferred choice if one is interested in sweet, heavier and bigger fruits.

\section{Acknowledgement}

The author wish to thank Mr. Suoye Spiff, the chief technologist of the chemical analytical laboratory of the Niger Delta University, for assessing the phytochemicals of the postharvest Irvingia fruits.

\section{References}

Agbor, G. A., Oben, J. E., Ngogang, J. Y., Xin, X. C., \& Vinson, J. A. (2005). Antioxidant capacity of some herbs/spices from Cameroon: A comparative study of two methods. J. Agric. Food Chem, 53, 6819-6824. http://dx.doi.org/10.1021/jf050445c

Alexopoulos, C. Y. (1962). Introduction to mycology (2nd ed.). John Wiley and Sons Inc. New York, p. 613.

Anegbeh, O., Usoro, C., Ukafor, V., Tchoundjeu, Z., Leakey, R. R. B., \& Schreckenberg, K. (2003). Domestication of Irvingia gabonensis: 3. Phenotypic variation of fruits and kernels in a Nigerian village. Agroforest. Sys, 58, 213-218. http://dx.doi.org/10.1023/A:1026094021408

Ashihara, H., Sano, H., \& Crozier, A. (2008). Caffeine and related purine alkaloids: biosynthesis, catabolism, function and genetic engineering. Phytochem, 69(8), 41-56.

Atangana, A. R., Tchoundjeu, Z., Fondoun, J. M., Asaah, E., Ndoumbe, M., \& Leakey, R. R. B. (2001). Domestication of Irvingia gabonensis: 1. Phenotypic variation in fruits and kernels in two populations from Cameroon. Agroforest. Sys, 53, 55-64. http://dx.doi.org/10.1023/A:1012293700774

Atangana, A. R., Ukafor, V., Anegbeh, P., Asaah, E., Tchoundjeu, Z., Fondoun, J. M., .. Leakey, R. R. B. (2002). Domestication of Irvingia gabonensis: 2. The selection of multiple traits for potential cultivars from Cameroon and Nigeria. Agroforest. Sys, 55, 221-229. http://dx.doi.org/10.1023/A:1020584823505

Barnett, H. L., \& Hunter, B. B. (1972). Illustrated General of Imperfect fungi (3rd ed.). Burgess Publishing Co. Minnesota, p.241.

Beresford, R. M., Evans, K. J., Wood, P. N., \& Mundy, D. C. (2006). Disease assessment and epidemic monitoring methodology for bunch rot (Botrytis cinerea) in grapevines. N. Z. Plant Prot, 59, 355-360.

Dennis, C., \& Davis, R. P. (1977). Susceptibility of strawberry varieties to post-harvest fungal spoilage. J. Appl. Microbiol, 42(2), 197-206. http://dx.doi.org/10.1111/j.1365-2672.1977.tb00685.x

Dennis, C., Davis, R. P., \& Harris, J. E. (1979). The relative importance of fungi in the breakdown of commercial samples of sulphited strawberries. J. Sci. Food Agric., 30(10), 959-973. http://dx.doi.org/10.1002/jsfa.2740301004

Di Carlo, G., Autore, G., Izzo, A. A., Maiolino, P., Mascolo, N., Viola, P., .. Capasso, F. (1993). Inhibition of intestinal motility and secretion by flavonoids in mice and rats: Structure-activity relationships. J. Pharm. Pharmacol, 45, 1054-1059. http://dx.doi.org/10.1111/j.2042-7158.1993.tb07180.x

Etebu, E. (2012). Postharvest pathology and phytochemicals of Irvingia gabonensis (Aubry-Lecomte ex O'Rorke) fruits and wastes. Agric. Sci. Res. J, 2(6), 285-294.

Etebu, E., Pasberg-gauhl, C., Gauhl, F., \& Daniel-Kalio, L. A. (2005). Effect of light and sealing patterns on sporulation and growth of Mycosphaerella fijiensis. InfoMusa, 14(1), 24-25.

Etebu, E., Tasie, A. A., \& Daniel-Kalio, L. A. (2003). Post-harvest fungal quality of selected chewing sticks. Oral dis, 9(2), 95-98. http://dx.doi.org/10.1034/j.1601-0825.2003.00803.x

Gomez, K. A., \& Gomez, A. A. (1984). Statistical procedures for agricultural research (2nd ed.). John Wiley and Sons, N.Y, p. 680.

Harbone, J. B. (1973). Phytochemical methods, London:Chapman and Hall, Ltd, pp. 49-188.

Harris, D. J. (1996). A revision of the Irvingiacea in Africa. Bulletin du Jardin Botanique National de Belgique, 65, 143-196. http://dx.doi.org/10.2307/3668184

Ilondu, E. M. (2011). Evaluation of some aqueous plant extracts used in the control of pawpaw fruit (Carica papaya L.) rot fungi. J. Appl. Biosci, 37, 2419-2424.

Isomoto, H., Furusu, H., Ohnita, K., Wen, C. Y., Inoue, K., \& Kohno, S. (2005). Sofalcone, a mucoprotective 
agent, increases the cure rate of Helicobacter pylori infection when combined with rabeprazole, amoxicillin and clarithromycin. World J. Gastroenterol, 11, 1629-1633.

Joseph, K., \& Aworh, O. C. (1991). Composition, sensory quality and respiration during ripening and storage of edible wild mango (Irvingia gabonensis). Int. J. Food Sci. Technol, 26, 337-342. http://dx.doi.org/10.1111/j.1365-2621.1991.tb01170.x

Joseph, K., \& Aworh, O. C. (1992). Post-harvest treatment of wild mango (Irvingia gabonensis) for improved shelf life. Food Chem, 44, 45-48. http://dx.doi.org/10.1016/0308-8146(92)90256-2

Kobina, M. J., \& Ebenezer, O. (2012). Fruit borne mycoflora of Capsicum annum L (pepper), Abelmoschus esculentus L. Moench (okra), and Lycopersicon esculentum Mill. (tomato) from Accra metropolis. Afr. J. Food Sci, 6, 1-7.

Koyejo, A. O., \& Omokhua, G. (2001). Propagation studies on Irvingia wombulu (syn. Excelsa) Ex. Okafor and agroforestry specis. In: Proceedings of FAN Conference held in Abuja, $17^{\text {th }}-21^{\text {st }}$ Sept., 2001. pp. 183-187.

Kozakiewicz, Z. (1989). Aspergillus species on stored products. Mycol. Papers, 161, 1-188.

Kraus, T. E. C., Zasoski, R. J., Dahlgren, R. A., Horwath, W. R., \& Preston, C. M. (2004). Carbon and nitrogen dynamics in a forest soil amended with purified tannins from different plant species. Soil Biol. Biochem, 36, 309-321. http://dx.doi.org/10.1016/j.soilbio.2003.10.006

La, C. C., Villegas, I., Alarcón de la Lastra, C., Motilva, V., \& Martín, M. J. (2000). Evidence for protective and antioxidant properties of rutin, a natural flavone, against ethanol induced gastric lesions. J. Ethnopharmacol, 71, 45-53. http://dx.doi.org/10.1016/S0378-8741(99)00174-9

Leakey, R. R. B. (1999). Farmers top priority fruit trees. Agrofor. Today, 11(3-4), 11-15.

Leakey, R. R. B., Fondoun, J. M., Atangana, A., \& Tchoundjeu, Z. (2000). Quantitative descriptors of variation in the fruits and seeds of Irvingia gabonensis. Agrofor, 50, 47-58. http://dx.doi.org/10.1023/A:1006434902691

Leakey, R., Schrecheriberg, K., \& Tchoundjev, Z. (2003). The participatory domestication of West African indigenous fruits. Int. For. Rev., 5, 338-347. http://dx.doi.org/10.1505/IFOR.5.4.338.22652

Lima, J. T., Almeida, J. R. G. S., Barbosa-Filho, J. M., Assis, T. S., Silva, M. S., da-Cunha, E. V. L., ... Silva, B. A. (2005). Spamolytic action of diplotropin, a furanoflavan from Diplotropis ferruginea Benth., involves calcium blockage in guinea-pig ileum. J. Chem. Sci, 60, 1093-1100.

Lowe, A. J. A., Gillies, C. M., Wilson, J., \& Dawson, I. K. (2000). Conservation genetics of bush mango from central/west Africa: Implications from random amplified polymorphic DNA analysis. Mol. Ecol, 9, 831-841. http://dx.doi.org/10.1046/j.1365-294x.2000.00936.x

Matos, L., Nzikou, J. M., Matouba, E., Pandzou-Yembe, V. N., Mapepoulou, T. G., Linder, M., \& Desobry S (2009). Studies of Irvingia gabonensis seeds kernels: Oil technological applications. Pak. J, Nutr, 8, 151-157.

Mert-Türk, F. (2006). Saponins versus plant fungal pathogens. J. cell Mol. Biol, 5, 13-17.

Ndoye, O., Pérez, M. R., \& Eyebe, A. (1997). The markets of non-timber forest products in the humid zone of Cameroon. Network No, 22 Rural Development Forest Network, Overseas Development Institute, London.

Ngondi, J. L., Oben, J. E., \& Minka, S. R. (2005). The effect of Irvingia gabonensis seeds on body weight and blood lipids of obese subjects in Cameroon. Lipids in health and Disease, 4, 12-15. http://dx.doi.org/10.1186/1476-511X-4-12

Nierop, K. G. J., Verstraten, J. M., Tietema, A., Westerveld, J. W., \& Wartenbergh, P. E. (2006). Short- and long-term tannin induced carbon, nitrogen and phosphorus dynamics in Corsican pine litter. Biogeochem, 79, 275-296. http://dx.doi.org/10.1007/s10533-005-5274-0

Okafor, J. C. (1975). Varietal delimination in Irvingia gabonensis (Irvingiaceae). Bulletin du Jardin Botanique Nationale de Belgique, 45(1-2), 211-221. http://dx.doi.org/10.2307/3667601

Okafor, J. C. (1985). Selection and improvement of indigenous tropical fruit tree: Problems and prospects. $J$. Forest Res., 1, 87-95.

Okafor, J. C. (1991). Improving edible species of forest products. UNASYLVA, 165, 17-23.

Okafor, J. C., Ejkiofor, M., \& Okolo, H. C. (1996). Development and utilisation of disappearing and under 
utilised edible wood forest species of southeastern Nigeria. Final Technical Report of Project Grant No. 7536. Biodiversity Support Programme. WWF, Washington, D. C.

Parsaeimehr, A., Sargsyan, E., \& Vardanyan, A. (2011). Expression of secondary metabolites in plants and their useful perspective in animal health. ABAH BIOFLUX, 3(2), 115-124.

Perrone, G., Susca, A., Cozzi, G., Ehrlich, K., Varga, J., Frisvad, J. C., ... Samson, R. A. (2007). Biodiversity of Aspergillus species in some important agricultural products. Stud. Mycol, 59, 53-66. http://dx.doi.org/10.3114/sim.2007.59.07

Prusky, D., \& Keen, N. T. (1993). Involvement of preformed antifungal compounds in the resistance of subtropical fruits to fungal decay. Plant Dis., 77, 114-119. http://dx.doi.org/10.1094/PD-77-0114

Rice-Evans, C., Miller, N., \& Pagana, G. (1997). Antioxidant properties of phenolic compounds. Trend Plant Sci, 2, 152-159. http://dx.doi.org/10.1016/S1360-1385(97)01018-2

Sanchez, P. A., \& Leakey, R. R. B. (1997). Land use transformation in Africa: three determinants for balancing food security with natural resource utilization. Euro. J. Agron, 7, 15-23. http://dx.doi.org/10.1016/S1161-0301(97)00034-8

Sofowora, A. (1993). Medicinal plants and traditional medicine in Africa: Spectrum Books Ltd, Ibadan, Nigeria, p. 289.

Sunairi, M., Watanabe, K., Suzuki, T., Tanaka, N., Kuwayama, H., \& Nakajima, M. (1994). Effects of anti-ulcer agents on antibiotic activity against Helicobacter pylori. Eur. J. Gastroenterol. Hepatol. 6 (Suppl. 1), S121-S124.

Trease, G. E., \& Evans, W. C. (1989). Text book of Pharmocognosy (13th ed.). Alden Press; Oxford, pp. 512-513.

Wink, M. (1988). Plant breeding: importance of plant secondary metabolites for protection against pathogens and herbivores. Theor. Appl. Genet, 75, 225-233. http://dx.doi.org/10.1007/BF00303957 